\title{
Planning in L1 and L2 writing: Working memory, process, and product - CORRIGENDUM
}

\author{
Mark D. Johnson
}

DOI: 10.1017/S0261444820000191 Published online by Cambridge University Press, 23 June 2020

The above mentioned article was submitted with some incorrect phrasing in the annotation Johnson, M. D. (2017).

This should have read:

In a research synthesis and meta-analysis of L2 writing research on TBLT, Johnson found planning to positively affect the complexity (syntactic and lexical) and accuracy of L2 written production, suggesting support for ROBINSON (2011) and SKEHAN (1998). Linking the findings to KELLOGG's (1996) model, the author suggests that planning may allow L2 writers to manage the writing process by focusing limited attentional resources on any of the writing systems (formulation, execution, or monitoring).

\section{Reference}

Johnson, M. D. (2020). Planning in L1 and L2 writing: Working memory, process, and product. Language Teaching, 1-13. doi:10.1017/S0261444820000191

Cite this article: Johnson, M. D. (2020). Planning in L1 and L2 writing: Working memory, process, and product CORRIGENDUM. Language Teaching, 53(4), 537-537. https://doi.org/10.1017/S0261444820000427

(c) The Author(s), 2020. Published by Cambridge University Press 